\title{
PÉNZÜGYI OKTATÁS A VILÁGBAN
}

Terták Elemér ${ }^{1}$

\begin{abstract}
ABSZTRAKT
Az elmúlt két évtized során a pénzügyi oktatás világszerte egyre fontosabb eszközévé vált a pénzügyi befogadás - tehát a pénzügyi szolgáltatásokhoz való hozzáférés és az esélyegyenlőség - kiteljesítésének, a fogyasztói jólét növelésének, valamint a pénzügyi rendszerek stabilitása megerősítésének az érdekében. A pénzügyi oktatás az 1990-es években került először a nagypolitika látókörébe, de széles körü politikai támogatást különösen a 2007-2008-as globális pénzügyi válság óta élvez. A tanulmány először a pénzügyi oktatás történelmét ismerteti, bemutatva a fejlődés fő állomásait. Ezt követően a tanulmány a pénzügyi oktatás különféle formáit, hatékony megvalósulását, valamint az oktatás és a szabályozás kölcsönhatásait veszi szemügyre, és bemutatja a pénzügyi oktatással kapcsolatos legfőbb vitákat, így pl. az oktatás és a tanácsadás vagy az oktatás és a szabályozás viszonyát, valamint a pénzügyi oktatásnak a személyes autonómiára gyakorolt hatását.
\end{abstract}

JEL-kódok: A20, D14, D19, D83, D91, G41, G53, N20, N7

Kulcsszavak: pénzügyi oktatás, pénzügyi müveltség, pénzügyi oktatás hatékonysága és költségei

\section{BEVEZETÉS}

Az elmúlt két évtized során a pénzügyi oktatás világszerte egyre fontosabb eszközévé vált a pénzügyi befogadás - tehát a pénzügyi szolgáltatásokhoz való hozzáférés és az esélyegyenlőség - kiteljesítésének, a fogyasztói jólét növelésének, valamint a stabil pénzügyi rendszerek stabilitásának a megerősítésének az érdekében. A pénzügyi oktatás az 1990-es években került igazán a nagypolitika látókörébe, de széles körü politikai támogatást különösen a 2007-2008-as globális pénzügyi válság óta élvez.

Mi áll ennek az érdeklődésnek a hátterében? A Gazdasági Együttmüködési és Fejlesztési Szervezet (OECD) 2020 folyamán három földrész - Ázsia, Európa és

1 Terták Elemér elnökségi tag, Magyar Közgazdasági Társaság, felügyelöbizottsági elnök, K\&H Bank Zrt. E-mail: elemertertak@gmail.com. 
Latin-Amerika - huszonhat országában, köztük 12 OECD-tagországban készített felmérést a pénzügyi ismeretekről (OECD-INFE, 2020). Az alapvető pénzügyi készségeket, magatartásokat és attitüdöket az OECD/INFE egységes pontozási módszerével mérték fel. A válaszok feldolgozása alapján a pénzügyi műveltség színvonala mind a 26 országban meglehetösen alacsonynak mutatkozott. Az egyének a teljes mintában átlagosan mindössze 12,7 pontot értek el, vagyis valamivel kevesebbet, mint a pénzügyi műveltség maximális pontszámának a 61\%-át. A felmérésben részt vevő OECD-tagországok átlaga csak alig volt ennél magasabb, 13,0 (a maximum 62\%-a). A legmagasabb pontszámot - 14,8 pontot, azaz a maximum 71\%-át Hongkong (Kína), míg a legalacsonyabb pontszámot - 11,1 pontot, azaz a maximum 53\%-át - Olaszország érte el. A többi ország 12 és 14 közötti pontot szerzett (l. 1. ábra).

\section{1. ábra}

\section{OECD-felmérés a pénzügyi ismeretekről}

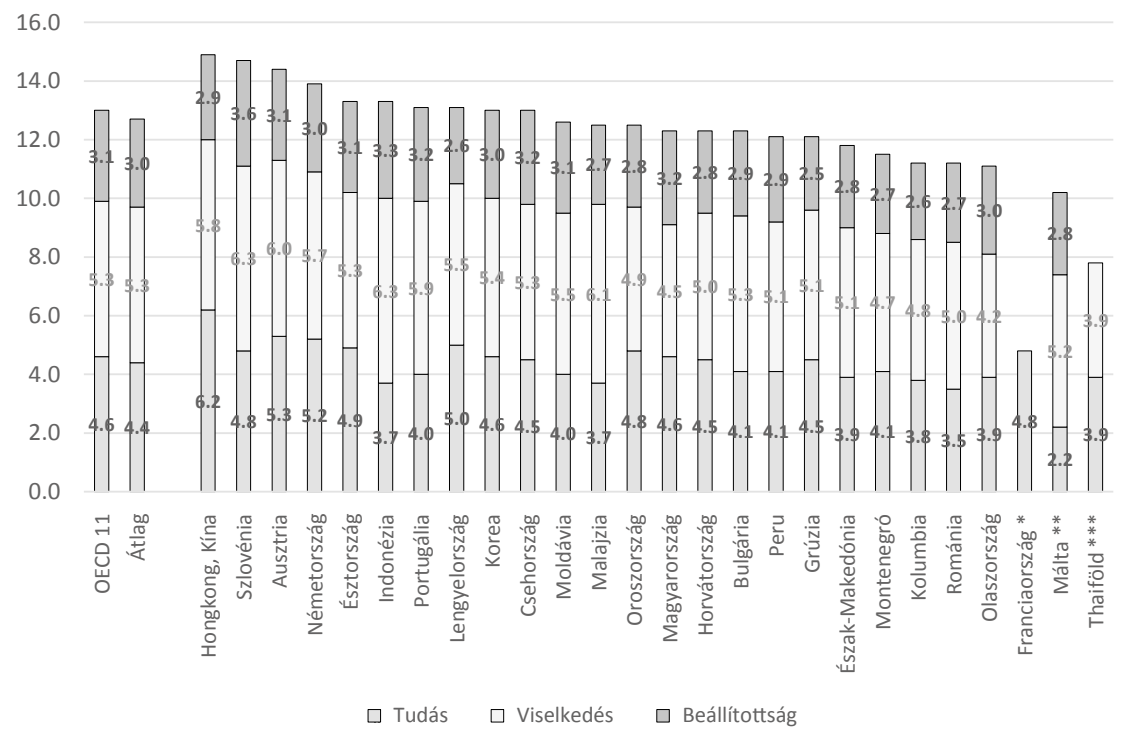

Megjegyzés: A *-gal jelzett országok esetén - amint az az ábrából is kitűnhet - a felmérés tartalma szükebb volt.

Forrás: OECD, 2020

A válaszokat az életkor alapján csoportosítva, a fiatalok (18-29 évesek) mindegyik országban feltűnően alacsonyabb szintü pénzügyi ismeretekkel rendelkeztek, és kevésbé körültekintő pénzügyi magatartás jellemezte őket. A középkorúak (30-59 évesek) csoportja jóval magasabb pontszámot ért el a pénzügyi kultúra és 
annak összetevői terén. Az idősek (6o év felettiek) viszont - kevés kivételtől eltekintve - szinte valamennyi országban alacsonyabb szintű pénzügyi ismeretekkel rendelkeztek, emellett pénzügyi magatartásuk általában kevésbé körültekintőnek mutatkozott.

A digitális eszközöket vagy szolgáltatásokat rendszeresen használó válaszadók minden országban feltünően magasabb szintű pénzügyi ismeretekkel, tudással, viselkedéssel rendelkeztek. Ez arra utal, hogy a digitális pénzügyi szolgáltatások intenzív használata magasabb színvonalú pénzügyi ismeretek meglétét és körültekintőbb pénzügyi magatartási mintát feltételez, ami implicit módon bizonyítja a pénzügyi oktatás fontosságát.

Végezetül a felmérés szerint azok az egyének, akik legalább három hónapnyi jövedelemnek megfelelő megtakarítással rendelkeznek, szinte kivétel nélkül lényegesen magasabb pontszámot értek el minden területen, mint azok, akik nem rendelkeztek ilyen megtakarítással. Ez a megfigyelés a tudatosság fontosságát támasztja alá, aminek a kialakulásában a pénzügyi oktatásnak fontos szerepe van.

A felmérésből levonható egyik figyelemre méltó következtetés az, hogy a pénzügyi müveltség szintje egy küszöbérték fölött kölcsönviszonyba kerül a gazdasági fejlettség szintjével, ugyanakkor a pénzügyi műveltség színvonala kivétel nélkül minden országban a kívánatosnál alacsonyabbnak bizonyult, azaz mindenütt van (volna) tere a pénzügyi oktatásnak (2. ábra).

\section{2. ábra}

\section{GDP/fö és a pénzügyi müveltség szintje}

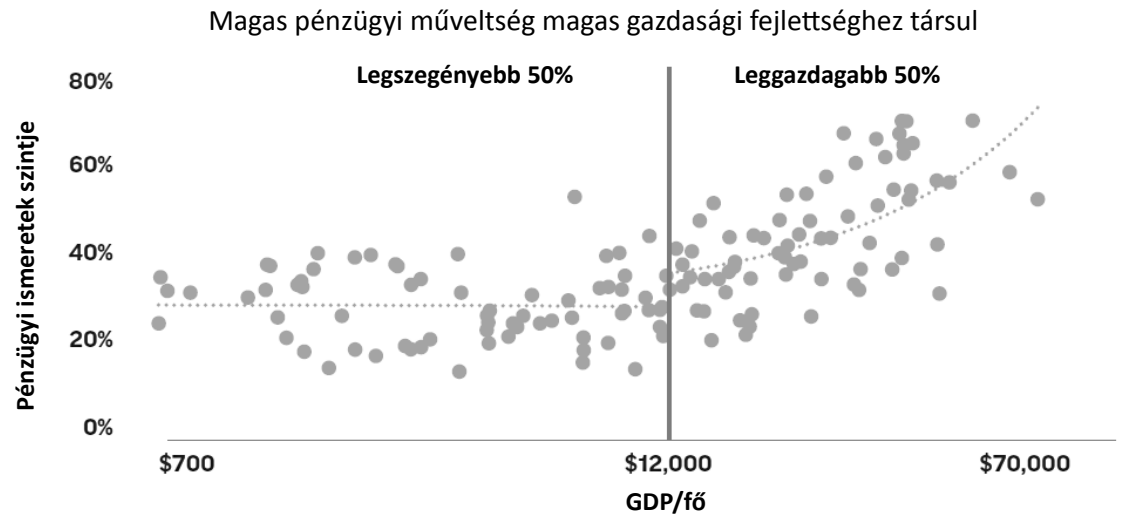

Forrás: S\&P Global FinLit Survey, 2016

Az említettek ellenére a pénzügyi oktatás társadalmi haszna a vitatott kérdések közé tartozik. Mint arra az Economist egyik cikke is felhívta a figyelmet (The Eco- 
nomist, 2008b), vannak, akik szerint a pénzügyi oktatás széles körü kiterjesztése valójában tévút, mert az társadalmi szinten sem nem hatékony, sem nem gazdaságos. E nézetek képviselői szerint empirikusan nem igazolható, hogy az intenzív pénzügyi oktatás elejét venné minden elhibázott pénzügyi döntésnek, pénzügyi pániknak, vagy megvédene mindennemü pénzügyi csalás elszenvedésétől. Véleményük szerint költség-haszon elemzés alapján nagyobb társadalmi haszna volna a pénzügyi szabályozás és a fogyasztóvédelem további szigorításának, esetenként pedig az ingyenes személyes pénzügyi tanácsadásnak, mint a pénzügyi ismeretek kötelező oktatásának, vagy a felnőttképzés terén tett erőfeszítéseknek.

A téma tárgyilagos elemzői általában elismerik, hogy az eddigi kutatások valóban nem mutattak ki szoros ok-okozati összefüggést a pénzügyi oktatás, illetőleg a magasabb pénzügyi műveltség, valamint a célszerűbb pénzügyi magatartás és a háztartások kedvezőbb pénzügyi helyzete között. Ez azonban szerintük nem a pénzügyi oktatás felesleges voltát igazolja, ugyanis a mérsékelt eredményességnek inkább az az oka, hogy a pénzügyi döntések meghozatalában nemcsak az oktatás keretében elsajátított ismeretanyag játszik szerepet, hanem számos szubjektív, például érzelmi indíték vagy hatás, valamint olyan nehezen számszerüsíthető egyéb tényezők is, mint mondjuk a társadalmi szokások, normák és hagyományok. Ezekkel a tényezőkkel egy még viszonylag fiatalnak mondható tudományterület, a „behavioural finance”, avagy magyarul a viselkedési pénzügytan foglalkozik.

A felmerült kétségek ellenére világszerte intenzív erőfeszítéssel dolgoznak a pénzügyi oktatás kiterjesztésén és hatékonyabbá tételén. Napjainkban számos kormány és társadalmi szervezet foglalkozik komolyan a pénzügyi oktatás fejlesztésével, amint azt több ország és közintézmény példája is bizonyítja az OECD Nemzetközi Pénzügyi Oktatási Portálján. ${ }^{2}$ A szakértők széles körében ugyanis az a meggyőződés vált uralkodóvá, hogy az emberek többsége akkor is jobb pénzügyi döntéseket hoz, komolyabb öngondoskodást tanúsít, s nagyobb biztonsági tartalékot halmoz fel egy válság átvészelésére megfelelő pénzügyi oktatás esetén, mint anélkül. Emellett a pénzügyi oktatás szószólói rámutatnak arra is, hogy a hatékonysági kutatások eddig főként a költség-haszon elemzésre összpontosítottak, viszont figyelmen kívül hagyták a viselkedési pénzügytan eredményeit, valamint a pénzügyi oktatást a közösségi médiákban kiegészítő, tudatos befolyásolás hatásmechanizmusának a vizsgálatát. Ez utóbbiak pedig azért lényegesek, mert a pénzügyi oktatás hatékonyságát vizsgáló legújabb kutatások szerint például a népszerü közösségi médiumokon meghatározott célcsoportokra fókuszálva az

2 OECD Financial Education, https://www.oecd.org/financial/education/. A magyar kormány stratégiáját 2017-ben alkották meg (NGM, 2017). 
influenszerek közremüködésével nyújtott pénzügyi képzések jól mérhető javulást eredményeztek a részt vevő háztartások pénzügyi helyzetében, továbbá jól segítették az átállást a 2010 óta gyorsan terjedő digitális bankolásra, aminek a jelentősége különösen a 2020-ban kitört koronavírus-járvány következtében nőtt meg. A cikk a továbbiakban a pénzügyi oktatás történetét kívánja áttekinteni, majd részletesen foglalkozik a pénzügyi oktatás hatékonyságának egyes kérdéseivel, s azok különböző nemzetközi aspektusaival. A pénzügyi oktatásnak a hazai és az Európai Unión belüli helyzetéről, eredményeiről a Gazdaság és Pénzügy folyóiratnak ez a tematikus száma további három tanulmány $t^{3}$ is tartalmaz, amelyek a jelen írással együtt, egymást kiegészítve adnak átfogó betekintést e fontos téma időszerű feladataiba és a további teendőkbe.

\section{A PÉNZÜGYI OKTATÁS TÖRTÉNETE}

A pénzügyi kultúra fejlődéstörténetének az áttekintése azt mutatja, hogy a középkortól a 19. század elejéig a pénzügyi ismeretek oktatásában hosszú ideig nem következett be változás.

Jóllehet különböző társadalmak már jóval az időszámítás előtt ismerték és használták a pénzt, a pénzügyi ismeretek oktatása és a pénzügyi befogadás kérdése mégis csak alig több mint 200 éves múltra tekint vissza. Ez persze nem jelenti azt, hogy az embereknek korábban egyáltalán ne lettek volna ismeretei a pénzről, de az ismeretek a pénzre mint forgalmi eszközre korlátozódtak, hiszen a hétköznapok során az emberek túlnyomó többsége szinte csak erre használta a fémérméket.

Az 5. század elejétől Nyugat-Európa gazdasága gazdasági és monetáris szempontból megtorpant, korlátozott volumenü csere és csekély pénzforgalom jellemezte. Az emberek ugyan ebben a korszakban is használtak pénzérméket, de müködő pénzrendszer gyakorlatilag nem létezett. Az emberek közötti elszámolások többnyire természetbeni fizetések formájában történtek, még akkor is, ha a fizetés keretében érmék átadására is sor került. A középkori gondolkodóknak - köztük Aquinói Szent Tamásnak - fenntartásai voltak a termékek áruvá válásának folyamatával szemben, de kiváltképpen ellenezték a pénz áruként történő adás-vételét, a pénz kölcsönzését uzsorára (kamatra) pedig egyenesen bünnek minősítették. ${ }^{4}$ A pénz alárendelt szerepe miatt a feudalizmus alatt a gazdasági élet egyetlen területe sem igényelt matematikai ismereteket, hiszen a kezdetleges földmüveléssel együtt járó kezdetleges iparnak és kereskedelemnek sokszor még a négy alapmü-

3 Kovács-Nagy (2022), Kovács-PÁsztor (2022), Németh (2022).

4 L. pl. Kovács Levente (2018): Gazdaságetika és jövőkép. Credo, 24(1-2), 9-99. 
veletre sem volt szüksége. Ebben a korszakban némi számolási ismeretre csak a legegyszerűbb alapvető mérési és számítási feladatok elvégzéséhez volt szükség; ezekhez segédeszközként mérleget és számolótáblát használtak. ${ }^{5}$

A feudális mezőgazdasági társadalomból a tőkés ipari társadalomba való átmenetet a vidékről való elvándorlás, s a három-öt generáció együttélésével megvalósuló családi kooperációként működő nagycsaládok felbomlása jellemezte. Az ipari forradalom, a városi népesség gyors növekedése, a bérmunkásság és pauperizáció kialakulása stb. mind olyan változásokat hoztak a pénz mindennapi használatában, ami már az addigi alapismereteken túlmenő tudást is igényelt. Így például az áruk és szolgáltatások természetbeni cseréjét kiszorította a pénzben való elszámolás, a napi szükségletek miatti kiadások teljesítése időben elvált a bérek heti vagy havi kifizetésétől, s ezért megjelent a rövid lejáratú hitel. E változások következtében a pénz önálló életet kezdett élni fizetési eszköz funkciójában, fontossá vált az időtényező is, és ezzel szükségessé vált a kamatszámítás. Emellett a hagyományos, többgenerációs családszerkezet felbomlása egyre nélkülözhetetlenebbé tette az öngondoskodás megszervezését akár betegségre, akár az öregkorra. Először a filantrópokban fogant meg annak eszméje, hogy a gyorsan szaporodó létszámú, szegény városi néposztályt takarékosságra neveljék és öngondoskodásra buzdítsák, hogy ezáltal javuljon az anyagi helyzetük és váratlan helyzetre rendelkezzenek valamekkora biztonsági tartalékkal is. Ennek a szociálpolitikai gondolatnak voltak szülöttjei a takarékpénztárak. Az első takarékpénztárakat emberbarátok és emberbaráti tevékenységet folytató jótékonysági egyesületek alapították a 18. század végén Németországban (Hamburg, 1778), Svájcban (Bern, 1787) majd Angliában. ${ }^{6}$ Ezekhez társultak később a községek által felállított takarékpénztárak, amelyek a valamivel később megalakuló falusi és városi szövetkezeti pénztárakkal együtt az ügyfeleik és tagjaik körében már nem csupán betétet gyüjtöttek, hanem esetenként hitelt is nyújtottak, emellett fontos küldetésüknek tekintették a dolgozók takarékosságra történő nevelését. A 19. század végére pedig már az iskolákban is elkezdték a gyermekeket arra ösztönözni, hogy akár néhány fillért is tegyenek rendszeresen félre, ezáltal megtanítva őket arra, hogy a megtakarítás erény.

A 19. század során a takarékoskodó, pénzével gondosan sáfárkodó lakosság gazdasági szerepe, nemzetgazdasági fontossága folyamatosan nőtt, ezért a takarékosságra való nevelés ügyét a 20. század elejétől egyre több szervezet és intéz-

5 SAin Márton (1986): Nincs királyi út! Matematikatörténet. Budapest, Gondolat, 433-467.

6 Heller Farkas (1947): Közgazdaságtan, II. kötet, 61. Ausztriában 1819-ben alapították egyesületi formában az első takarékpénztárt „Erste österreichische Spar-Casse” néven. Az első magyar takarékpénztárt Fáy András kezdeményezésére Pesti Hazai Első Takarékpénztár néven 1839-ben alapították meg egyesületi formában. 
mény karolta fel. A felívelő fejlődésben súlyos törést okozott az I. világháború, majd a világháborút követő évek gazdasági válsága. Főleg a vesztes országokban kirobbant hiperinfláció jócskán elértéktelenítette a korábbi megtakarításokat, s csökkentette az emberek megtakarítási képességét is. A húszas évek közepétől kibontakozott fellendülés azonban ismét lehetővé tette az egyéni megtakarításokat. Ennek serkentéséül az I. Nemzetközi Takarékpénztári Kongresszus (First International Thrift Congress) 1924-ben kezdeményezte, hogy a következő évtől kezdve minden év október utolsó hetében tartsák meg a megtakarítások világnapját. Ez az esemény a kezdetekben a megtakarítások eszméjének népszerüsítését szolgálta. Néhány kezdeményező országban a megtakarítások világnapja napjainkra már elveszítette az eredeti jelentőségét, ám a feltörekvő országok többségében a „takarékosság világnapja” változatlanul fontos szerepet játszik az öngondoskodás erősítésében, egyszersmind tükrözi a pénzügyi oktatás fontosságát is.

A második világháborút követően az öngondoskodás növekvő fontossága mellett a pénzügyi müveltség kérdése is egyre nagyobb figyelmet kapott a globális pénzügyi piacok és az azokon forgalmazott termékek egyre összetettebbé válása, a pénzügyi szolgáltatások terén is végbemenő müszaki forradalom, valamint a pénzügyi befogadás kiszélesítésének az igénye miatt. Ebben az időszakban a lakásigények kielégítése, valamint a háztartások tartós fogyasztási eszközökkel való ellátottsága növekvő mértékben a háztartások hitelfelvételétől kezdett függeni. Emiatt az 1990-es évekre egyre több kormányzati szervezet ismerte fel, hogy a fiataloknak már az iskolában komoly pénzügyi oktatásra van szükségük ahhoz, hogy a felnőtté válásuk időpontjában képesek legyenek megalapozott döntéseket hozni olyan fontos kérdésekben, mint az önálló lakáshoz jutás vagy a nyugdíjrendszerhez való csatlakozás módja. Ugyanakkor a fiatalok többsége ekkortájt még úgy fejezte be az iskolai tanulmányait, hogy jószerint alig tanult valamit az iskolában a pénzről meg a pénzügyi rendszer működéséről, holott akár továbbtanultak, akár munkába álltak, hirtelen több nagy horderejü, anyagi helyzetüket hosszú távon meghatározó pénzügyi döntést kellett meghozniuk.

Ennek az ellentmondásos helyzetnek a felismeréstől vezéreltetve az Egyesült Államokban 1997-ben több mint 150 vállalati, tudományos, közhasznú és kormányzati szervezet létrehozta a Jump\$tart (magyarul ugrásszerű indítás) elnevezésű társulást, amelynek tagjai közösen léptek föl a pénzügyi oktatás fontosságának elismertetése és bevezetése érdekében, továbbá gondoskodtak a szükséges tananyagok kidolgozásáról, valamint az oktatás megszervezésének és működtetésének a forrásairól.7 A társulás a megalapítása óta rendszeresen végez felméréseket a végzős középiskolások pénzügyi müveltségi szintjéről is. A 2005-ben készített,

7 https://www.jumpstart.org/who-we-are/about/history/. 
első átfogó felmérés szerint a középiskolások átlagos pontszáma mindössze 52 százalékos szintet ért el az egyesült államokbeli osztályozási skálán, s a megkérdezett diákoknak csupán 16 százaléka vett részt legalább egy teljes tanfolyamon a személyes pénzügyekről.

2002 októberében az amerikai pénzügyminisztérium közzétette a pénzügyi oktatásnak az iskolai tantervekbe történő beépítéséről szóló fehér könyvét. ${ }^{8}$ Ebben rámutatott a pénzügyi ismereteknek a matematika és az állampolgári ismeretek tantárgyak tantervébe történő beillesztésének fontosságára. Ugyancsak fontos szerepet kapott a 2003 decemberében elfogadott Fair and Accurate Credit Transactions Act (méltányos és pontos hitelügyletek - FACTA) elnevezésü törvény, amelynek az elsődleges célja ugyan a fogyasztók védelme volt a hitelinformációs rendszerekben, de a törvénynek a „Financial Literacy and Education Improvement" címet viselö, ötödik fejezete a pénzügyi műveltség és az oktatás javításáról is tartalmazott fontos rendelkezéseket. ${ }^{9}$ E törvény a pénzügyminisztert tette meg az újonnan felállított Pénzügyi Müveltségi és Oktatási Bizottság vezetőjének. Azt is elrendelte, hogy a pénzügyminisztérium 19 más szövetségi minisztériummal és felügyeleti hatósággal összefogva, e bizottság keretében gondoskodjon a pénzügyi műveltség előmozdításáról az állami és a magánszektor együttmüködésére építve.

Ezt követően George W. Bush elnök 2008. január 22-én létrehozta a pénzügyi müveltséggel foglalkozó elnöki tanácsadó testületet. ${ }^{10} \mathrm{E}$ testület abban adott tanácsot az elnöknek, hogy miként lehet növelni a fiatalok és a felnőttek pénzügyi ismereteit és készségeit az iskolákban, a munkahelyen vagy a lakóhelyen, s miként lehet ezen keresztül erősíteni a fogyasztóvédelmet. A tanács tagjai közé olyan egyetemek, alapítványok és vállalkozások képviselői is bekerültek, amelyek valamilyen formában rendszeres pénzügyi oktatást végeznek. 2013-ban Barack Obama elnök módosította a tanácsadó testület feladatát és összetételét, mégpedig a fiatalok képzésével kapcsolatos kérdésekre fókuszálva. A tanácsadó testület mandátuma ajánlások kidolgozásával 2015 júniusában szűnt meg.

8 United States Department of the Treasury (2002): Integrating Financial Education into School Curricula: Giving America's Youth the Educational Foundation for Making Effective Financial Decisions throughout Their Lives by Teaching Financial Concepts as Part of Math and Reading Curricula in Elementary, Middle, and High Schools. A White Paper, Office of Financial Education, Washington DC., October 2002.

9 https://www.govinfo.gov/content/pkg/PLAW-108publ159/html/PLAW-108publ159.htm.

10 White House (2008): President Bush Announces President's Advisory Council on Financial Literacy, January 22, https:/georgewbush-whitehouse.archives.gov/news/releases/2008/o1/ images/20080122-7_p012208sc-0321-515h.html. 
Mint az a rövid áttekintésből is kitünhetett, az Egyesült Államokban már viszonylag régebb óta szentelnek nagy figyelmet a pénzügyi oktatás ügyének. Ennek az a magyarázata, hogy az Egyesült Államokban (s több más angolszász országban) a tőkepiac dominanciáján alapuló pénzügyi rendszer alakult ki, ahol a kölcsönnyújtás, biztosítási és befektetési termékek szabályozásának uralkodó modellje a szolgáltatók szigorú nyilvános tájékoztatási kötelezettségén és a fogyasztók szabad választási jogán alapul. Ez a szabályozási modell a „homo oeconomicus” embertípus $^{11}$ feltételezésén alapul, amely szerint az ember racionális, világos preferenciarendszerrel rendelkezik, ennek az alapján sorba tudja rendezni a választási lehetőségeit, amelyek közül haszonmaximalizáló lévén, azt választja, ami számára a „legelőnyösebb”, azaz a legnagyobb hasznot eredményezi. Ahogy azonban idővel a különböző pénzügyi termékek egyre összetettebbekké váltak, az is egyre nyilvánvalóbbá lett, hogy ezeket az átlagos fogyasztók már képtelenek minden részletükben megérteni, aminek viszont idővel óhatatlanul súlyos társadalmi és gazdasági következményei is lehetnek. Ebből kiindulva a politikai döntéshozók a pénzügyi ismeretek oktatását a kibocsátók nyilvános tájékoztatási kötelezettségén alapuló szabályozási modell kulcsfontosságú elemének nyilvánították. A politikai döntéshozók szándéka szerint az oktatás révén a fogyasztók „felelős” és „döntésképes” piaci szereplőkké válnak, akik nemcsak motiváltak, hanem képesek is a saját jólétüket befolyásoló pénzügyi döntések felelős meghozatalára. A cél az, hogy a képzés révén a fogyasztók saját hitel-, biztosítási és nyugdíjtervezési ügyeiket úgy legyenek képesek intézni, hogy magabiztosan eligazodnak a piacon az egymással versengő szolgáltatók bőséges kínálata között.

Ez a vízió ugyan kétségtelenül vonzó, hiszen a kínálati oldal versenye és a keresleti oldal szabad választási lehetősége elméletileg növekvő fogyasztói jólétet ígér. A pénzügyi oktatás hasznosságába vetett hitet azonban a való élet csak korlátozottan igazolta. Ennek az az egyik alapvető oka, hogy a pénzügyi piacon számos és gyors változás megy végbe, ami a fogyasztók tényleges ismeretei és főleg az összetett, nem szabványosított pénzügyi termékek megértéséhez szükséges ismeretek között tátongó szakadékot szüntelenül szélesíti. Ezt a szakadékot tovább növeli a szolgáltatóknak a fogyasztók befolyásolására való képessége, a pénzügyi ismeretet oktató tanárok és a pénzügyi szolgáltatók szakembereinek ismeretei közötti információs és tudásbeli aszimmetria, s végül, de nem utolsó sorban a pénzügyi döntéshozatal során tapasztalható kognitív disszonancia.

A 2008-as globális pénzügyi válságra adott válaszintézkedések - a pénzügyi ismeretek fontosságának nyomatékos hangsúlyozása mellett - világszerte jócskán

11 Ld. erről James Chen (2021): What Is Homo Economicus?, Investopedia, https://www. investopedia.com/terms/h/homoeconomicus.asp. 
kiterjesztették a pénzügyi szektor szabályozásának a hatókörét, egyszersmind megnövelték annak terjedelmét és részletezettségét is. Noha általános egyetértés van a szabályozás szükségességét illetően, komoly nézetkülönbségek mutatkoznak abban, hogy a szabályozás összetettségének az elmúlt évek során végbement növekedése valóban szükséges volt-e. A banki és tőkepiaci szabályozás összetettebbé válása ugyanis potenciálisan csökkenti a szabályozás átláthatóságát, növeli a szabályozási arbitrázs veszélyét, jócskán megterheli a felügyeleti erőforrásokat, egyszersmind a pénzintézetekre oly mértékủ többletterhet ró, ami már a müködési költségek érzékelhető emelésével jár. A rendkívül összetetté váló szabályozás emellett paradox módon hozzájárul a rendszerkockázat növekedéséhez is. Először is azért, mert a szabályozás sürű szövedéke egy mindent átfogó és jól ellenőrzött rendszer látszatát kelti, ugyanakkor az átláthatatlanságával megkönnyíti és kifizetődővé teheti a felügyelt szervezetek számára a szabályok kijátszását. Másodszor azért, mert a „túl kifinomult” szabályozási rendszerek többnyire nem igazán alkalmasak az „ismeretlen ismeretlenek” ${ }^{12}$ kezelésére. Harmadszor pedig azért, mert a kockázatok bekövetkezése esetén a szabályozási eszközök széles köre és kombinációja bonyolulttá és nehezen megítélhetővé teheti a meghozott intézkedéseket, ez pedig nehezíti a szabályozók és a felügyeletek elszámoltathatóságát is. Végül, de nem utolsó sorban a szabályozás bonyolultsága ösztönözheti a kockázatoknak a szabályozási körön kívül eső intézményekre, így pl. a költségvetésre történő áthárítását is, ugyanakkor „felmenti” a fogyasztókat az alól, hogy megismerjék és megértsék a szabályokat, illetőleg felelősséget vállaljanak elhibázott egyedi döntéseikért. ${ }^{13}$

Mint azt a továbbiakban a tanulmány is bemutatja, napjainkra az Egyesült Államokban - és több más angolszász országban - komoly dilemmává vált, hogy miként lehet a pénzügyi rendszer biztonságát és a fogyasztók egyéni felelősségét társadalmilag hatékony módon összhangba hozni. Ki és milyen mértékben viselje a felelősséget a rendszer biztonságáért és a fogyasztók egyéni döntéseiért? Olyan társadalomban akarnak-e az emberek élni, ahol az átlagfogyasztóknak egyénileg kell eligazodniuk a pénzügyi termékek szüntelenül változó kínálatában, csupán az oktatás során szerzett tudásukkal felfegyverzetten? Képes-e a pénzügyi oktatás a pénzügyi döntéshozatal nem racionális tényezőit valahogy kiküszöbölni? S vajon a fogyasztók kívánnak-e olyan társadalomban élni, ahol a döntéseik hátrányos

$12 \mathrm{Az}$,ismeretlen ismeretlen” szállóige Donald H. Rumsfeld (1932-2021) volt amerikai hadügyminiszter egyik 2002-es beszédének elhíresült mondatából származik: „Vannak ismert ismeretek. Ezek azok a dolgok, amikről tudjuk, hogy tudjuk. Vannak ismert ismeretlenek. Ezek azok a dolgok, amikről tudjuk, hogy nem tudjuk. De vannak ismeretlen ismeretlenek is. Ezekről a dolgokról nem tudjuk, hogy nem tudjuk" (https://www.citatum.hu/idezet/108132).

13 L. erről pl. GaI et al., 2019. 
következményeit törvények és felhatalmazott intézmények „társadalmasítják”, de a beleszólásuk nélkül hozott döntések alapján? S vajon ez végső soron nem jelentene-e súlyos beavatkozást az emberek magánéletébe, és nem csökkentené-e az egyéni autonómiát? Megannyi kérdés, amelyre nem lehet egyszerü választ adni.

A világ más országaiban, ahol inkább a bankalapú pénzügyi rendszer dominál, az embereknek mint fogyasztóknak a védelme - az angolszász gyakorlattól eltérően - sokkal inkább a szabályozással, illetőleg a nyugellátásuknak a biztosítása főleg állami intézmények révén történik, a pénzügyi oktatás szerepe nem tünik olyan kiemelkedő fontosságúnak, mint például az Egyesült Államokban. Ám az egyéni választás és a döntés jogát és felelősségét ezekben az országokban sem lehet korlátozni, következésképpen - a jogi, intézményi és kulturális különbségek dacára - ezekben is egyre fontosabbá és sürgetőbbé vált a pénzügyi ismeretek oktatása. Annál is inkább, mert az emberek pénzügyi ismeretének a szintjéről végzett felmérések ezekben az országokban hasonló eredményeket mutattak, mint az amerikai vizsgálódások. Ezt tanúsítja például az OECD-INFE (2020) már hivatkozott felmérése is.

A pénzügyi ismeretek hiányosságainak, valamint az ezek kiküszöbölését célzó feladatok hasonlóságára tekintettel a Gazdasági Együttmüködési és Fejlesztési Szervezet (OECD) 2002-ben egy addig egyedülálló, átfogó nemzetközi projektet indított útjára a pénzügyi ismeretek oktatásának az előmozdítására. Ennek keretében az OECD azt javasolta, hogy a tagállamok a pénzügyi ismeretek oktatását az iskolákban a lehető legkorábban kezdjék meg. A tantervbe történő beépítés révén ugyanis a gyermekek számára már iskoláskoruktól kezdve lehetővé válik, hogy elsajátíthassák a felelős pénzügyi magatartás kialakításához szükséges ismereteket és készségeket. Ez pedig két ok miatt fontos: egyfelől az egész világon a szülők jelentős része nincs kellően felkészülve ahhoz, hogy gyermekeiket megtanítsák a pénz okos használatára, hiszen a pénzügyi ismeretek szintje a felnőttek körében is meglehetősen alacsony. Másfelől a gyermekek már általános iskolás korukban szembesülnek a pénzkezeléssel kapcsolatos problémákkal, hiszen szüleiktől rendszeresen kapnak zsebpénzt, sőt sokszor társkártyát is, középiskolás korukban pedig a fiatalok többsége már saját keresetből is rendelkezik pénzzel.

2008 márciusában az OECD létrehozta a Nemzetközi Pénzügyi Oktatási Hálózatot (INFE), amely támogatja a tagállamokat és a hálózathoz csatlakozó országokat a pénzügyi oktatási programok nemzeti stratégiáinak a kidolgozásában és végrehajtásában, továbbá innovatív módszereket dolgoz ki a lakosság pénzügyi ismereteinek javítására. ${ }^{14}$

14 https:/www.oecd.org/financial/education/oecd-international-network-on-financial-education. htm. 
Az INFE-nek jelenleg 270 közintézmény a tagja az OECD 34 tagállamából és a csatlakozó további 96 országból. A hálózat munkáját egy tanácsadó testület felügyeli. A hálózatban létrehozott munkacsoportok jelenleg a pénzügyi oktatáshoz kapcsolódó négy kulcsfontosságú szakpolitikai kérdéssel foglalkoznak:

1. Szabványok kidolgozása, végrehajtása és értékelése.

2. Pénzügyi oktatás és a digitalizáció hatásai.

3. Pénzügyi oktatás a munkahelyen.

4. A népesség elöregedésének hatása és az idősebb fogyasztók igényei.

Az INFE emellett folytatja a korábbi munkacsoportok eredményeinek továbbfejlesztését és megvalósítását, ideértve a következőket: a pénzügyi ismeretek alapvető elemei; pénzügyi oktatás mikro-, kis- és középvállalkozások számára; pénzügyi oktatás a pénzügyi befogadás elősegítésére; a pénzügyi oktatás nemzeti stratégiái; pénzügyi oktatás fiataloknak és nőknek; pénzügyi oktatás a hosszú távú megtakarítások és befektetések serkentéséhez; továbbá a pénzügyi kultúra mérése.

Az Európai Bizottság a pénzügyi szolgáltatásokra vonatkozó 2005 és 2010 közötti politikai prioritásait 2005 végén tette közzé egy fehér könyvben. Ebben egyebek mellett kimondta, hogy növelni kell a pénzügyi termékek átláthatóságát és összehasonlíthatóságát, továbbá segíteni kell a fogyasztókat abban, hogy jobban megértsék ezeket a termékeket. A pénzügyi ismeretek színvonala három ok miatt is fontos az EU-nak:

1) A gyorsan öregedő népesség miatt a hagyományos nyugdíjrendszerekre nehezedő nyomás csak az öngondoskodás szerepének a növelésével mérsékelhető, ennek az előmozdítása pedig magasabb szintű pénzügyi ismeretek révén érhetö el.

2) A jelzáloghitelek az euróövezeti háztartások teljes adósságállományának túlnyomó részét teszik ki. Ezért az eladósodás következményeinek a megértése különösen fontos a fiatal háztartások, az első lakást szerzők és az alacsony jövedelemmel rendelkező személyek számára, ehhez pedig elengedhetetlen a megfelelö pénzügyi ismeret.

3) A pénzügyi műveltség hiánya igazolhatóan hátráltatja a szegénység, az egyenlőtlenség, a társadalmi kirekesztettség leküzdését és a társadalmi felemelkedést.

Az Európai Bizottság szakpolitikai ajánlásai és programjai már az iskoláskortól kezdve célozzák a pénzügyi kultúra fejlesztését, főleg a fiatalok, a nők és az alacsony jövedelmü csoportok sajátos igényeihez igazított programok révén; továbbá célzott pénzügyi oktatást kívánnak biztosítani az olyan nagy horderejű pénzügyi 
döntések - mint pl. az első lakáshitel vagy a diákhitel felvétele, vagy a nyugdíjelőtakarékossági szerződés kiválasztása - előtt állók számára.

A Bizottság az OECD-vel is együttmüködve már 2003 decemberében elindította a DOLCETA (Developing On-Line Consumer Education and Training for Adults) online felnőttképzési projektjét. Ennek keretében a tagállamok szakértői fokozatosan nyolc modult dolgoztak ki, amelyek olyan területeket fedtek le, mint a pénzügyi ismeretek, a fogyasztói jog, a fenntartható fogyasztás és a termékbiztonság. A projekt fö célja az volt, hogy felhívja az uniós polgárok figyelmét a jogaikra és arra, hogy aktívan éljenek ezekkel. A projekt nemcsak a nagyközönséget célozta meg, hanem például a pénzügyi ismereteket oktató tanárok és nonprofit szervezetek számára is biztosított információkat és tananyagot. A portál az évek folyamán olyan többezer oldalas enciklopédiává vált, amelynek a szerzői a téma elismert szakértői voltak. 2013-ban a Bizottság, tekintettel a projekt frissítésének és fenntartásának magas költségeire, úgy döntött, hogy befejezi a DOLCETA projektet, és azt a „ConsumerClassroom.eu” projekttel helyettesíti. Az új projekt már nem a fogyasztók közvetlen tájékoztatására, hanem a 12 és 18 év közötti diákok pénzügyi oktatását végző középiskolai tanárok szakmai továbbképzésére, illetve tananyagaik kicserélésének elősegítésére irányul.

2020 szeptemberében a Bizottság (konkrétan a Pénzügyi Stabilitás, a Pénzügyi Szolgáltatások és a Tőkepiaci Unió Főigazgatósága) az EU tőkepiaci unió (CMU) cselekvési tervében szánt kiemelt szerepet a pénzügyi műveltség növelésének. ${ }^{15}$ Az erre irányuló projektet a Bizottság az INFE-vel közösen készíti elő és dolgozza ki. Az új kompetenciakeret a fiatalok pénzügyi ismereteiről, valamint a G2o/ OECD felnőttek pénzügyi műveltségéről szóló INFE-alapkompetenciák keretére épül, és felöleli a pénzügyi szolgáltatások digitalizációjával és a fenntartható finanszírozással összefüggő valamennyi kérdést. Az új EU-keret célja, hogy uniós szinten közös terminológiát és keretet teremtsen a pénzügyi ismeretekkel kapcsolatos szakpolitikák és programok kidolgozásához, az ellátás hiányosságainak azonosításához, valamint közös értékelési, mérési és értékelési módszerek alkalmazásához.

2017 februárjában az Európai Bizottságnak a pénzügyi műveltség növelésére irányuló törekvéseit kiegészítendő és azokat előmozdítandó, kilenc európai érdekképviseleti szövetségből és oktatási szervezetből álló csoport létrehozta az Európai Pénzügyi Oktatási Platformot, amely az INFE társult tagja lett. A kezdeményezés célja, hogy serkentse a pénzügyi oktatás iránti igényt és bővítse a pénzügyi ismereteket Európában, különösen a fiatalok és a vállalkozók körében.

15 https://ec.europa.eu/info/business-e.conomy-euro/banking-and-finance/consumer-financeand-payments/financial-literacy_hu. 
A platform alapító partnerei: a befektetőket és a megtakarítókat képviselő Better Finance; a befektetési szakemberek képzését végző CFA Intézet; az európai kereskedelmi és iparkamarákat tömörítő EUROCHAMBRES szövetség; a magánbankokat képviselő Európai Bankföderáció (EBF); Európai Banki és Pénzügyi Szolgáltatásokat Képzők Szövetsége (EBTN); az Európai Alap- és Vagyonkezelő Szövetség (EFAMA); Európai Mikrofinanszírozási Hálózat (EMN); a magánbiztosítókat tömörítő Insurance Europe; és a JA Europe vállalkozóképző intézmény. Az alapítók megállapodtak abban, hogy egyesítik erejüket az európai pénzügyi ismeretek fejlesztése érdekében. A platform eszmék, információk és tapasztalatok cseréjére szolgál, valamint konzultációkat szervez arról, hogy az Európai Unió miként játszhat vezető szerepet a pénzügyi kultúra fejlesztésében. A platform támogatni fogja a partnereket abban is, hogy összehangolják részvételüket az európai szintű kezdeményezésekben a lehetséges szinergiák kiaknázása és a párhuzamos munka elkerülése érdekében.

A pénzügyi ismeretek oktatását és a pénzügyi befogadást 2009-ben az Egyesült Nemzetek Szervezete is fontos feladatnak ismerte el. Az ENSZ fötitkára 2009ben Máxima holland királynét nevezte ki az inkluzív fejlesztési finanszírozás különleges megbízottjának (UNSGSA), aki ebben a minőségében tanácsot ad a főtitkárnak, és azon dolgozik, hogy a pénzügyi szolgáltatások mindenki számára elérhetővé váljanak, beleértve az alacsony jövedelmű népességcsoportokat és a kkv-szektort is. ${ }^{16}$ A Világbank Findex adatbázisa ${ }^{17}$ szerint 2017-ben világszerte mintegy 1,7 milliárd felnőtt, vagyis a teljes felnőtt lakosság fele nem fért hozzá a szabályozott pénzügyi intézmények által nyújtott pénzügyi szolgáltatásokhoz, így bankszámlához, biztosításhoz vagy hitelhez. Míg például a fejlett gazdaságokban a felnőttek 94 százaléka rendelkezik számlával valamely pénzintézetnél, addig a fejlődő országokban a felnőttek mindössze 54 százalékának van számlája. Az UNSGSA szerint a pénzügyi szolgáltatásokhoz való hozzáférés és az ezek használatához szükséges ismeretek elsajátítása létfontosságú a fenntartható gazdasági növekedés megteremtéséhez, a munkahelyteremtéshez, valamint az emberek személyes és társadalmi fejlődésének ösztönzéséhez.

A G2o országok állam- és kormányfői a 2009 szeptemberi pittsburghi csúcstalálkozón elhatározták, hogy a szegényeket támogató tanácskozó csoporttal (Consultative Group to Assist the Poor - CGAP) ${ }^{18}$, a Nemzetközi Pénzügyi Társasággal (IFC) és más nemzetközi szervezetekkel együttműködve létrehozzák a

16 https://www.unsgsa.org/.

17 https://globalfindex.worldbank.org/.

18 A washingtoni székhelyű CGAP a világ több mint 30 vezető fejlesztési bankjának, ügynökségének és alapítványának a globális partnersége. 
G2o pénzügyi befogadással foglalkozó szakértői csoportját. Ennek a csoportnak az egyik fontos feladatává tették a pénzügyi ismeretek terjesztésének elősegítését. A 2010. évi szöuli csúcstalálkozójukon pedig a pénzügyi integrációt jelölték meg a globális fejlesztési menetrend egyik fő pillérének, és elfogadták a G2o pénzügyi integráció cselekvési tervét (Financial Inclusion Action Plan - FIAP). Néhány hónappal később pedig megkezdte tevékenységét a Globális Partnerség a Pénzügyi Befogadásért (Global Partnership for Financial Inclusion - GPFI) a pénzügyi integráció globális előmozdítása érdekében. A GPFI egy úgynevezett befogadó platform a G2o tagállamok, a G2O-on kívüli országok és más érdekelt felek számára a pénzügyi integráció menetrendjének a végrehajtására. A GPFI munkája a prioritások, cselekvési területek és teljesítések szerint tagolódik, és céljai eléréséhez a végrehajtó partnerek támogatására támaszkodik. A fő cselekvési területek közé tartozik az egyének, valamint a mikro-, kis- és középvállalkozások digitális pénzügyi integrációját elősegítő intézkedések meghozatalának segítése, valamint a nemzetközi átutalási költségeknek a nemzetközileg célul kitűzött szintre csökkentése terén elért eredmények nyomon követése. A GPFI emellett ösztönzi a pénzügyi oktatási politikák kidolgozását, továbbá intézkedéseket és elveket javasol a pénzügyi szolgáltatások, különösen a digitális szolgáltatásokkal kapcsolatos pénzügyi ismeretek elterjesztésére, illetve az ilyen szolgáltatásokat igénybe vevő fogyasztók védelmének a megerősítésére. A GPFI tiszteletbeli védnöke 2011 júniusa óta Máxima holland királyné mint az ENSZ főtitkárának a fejlesztési inkluzív finanszírozásért felelős, különleges szószólója. A GPFI munkaprogramjának és tevékenységeinek irányításáért és koordinálásáért a G20-tagországok által kinevezett két társelnök felel, akik együttműködnek a G2o elnökségével, a GPFI „trojkával” (az előző, a jelenlegi és a jövőbeli társelnökökkel), valamint a GPFI összes tagjával. ${ }^{19}$

A 2020 elején kirobbant koronavírus-járvány miatti megszorítások, valamint a pénzügyi piac digitalizációjának a járvány által is serkentett fejlődése világszerte új kihívásokat jelentett a pénzügyi ismeretek oktatása terén is. Számos kormány a pénzügyi oktatási üzeneteinek és programjainak továbbítását online csatornákra vagy más digitális eszközre helyezte át. A világjárvány miatt elrendelt korlátozások miatt ugyanis a digitális úton történő továbbítás jelentette szinte az egyetlen járható útját annak, hogy a nemzeti hatóságok eljuttathassák a pénzügyi tárgyú tájékoztatási és képzési célú üzeneteiket a polgáraikhoz, különösen a pénzügyi nehézségekbe sodródott emberekhez. Az OECD/INFE által 2020 szeptemberében végzett felmérés (OECD-INFE, 2020) azt mutatta, hogy a legtöbb ország és hatóság sikeres erőfeszítéseket tett annak érdekében, hogy a koronavírus-járvány

19 https://www.bancaditalia.it/focus/g20-2021/temi-gruppi/gpfi/index.html?com.dotmarketing. htmlpage.language $=1$. 
idején átterelje a pénzügyi oktatást az internetre, és ezt a csatornát valószínűleg a járvány lecsengése után is alkalmazni fogják.

Amennyire örvendetes volt, hogy a digitális technikák alkalmazásával az - e-kereskedelem fellendülése következtében is megugrott - készpénzmentes fizetési forgalmat a koronavírus-járvány miatti kényszerü korlátozások közepette is zavartalanul lehetett lebonyolítani, annyira sajnálatos módon észlelték az interneten megkísérelt és elkövetett pénzügyi csalások számának szintén ugrásszerü növekedését is. Ez azzal a kihívással járt, hogy a fogyasztókkal - köztük különösen a legsebezhetőbbekkel - meg kellett értetni a digitális pénzügyi szolgáltatások előnyei mellett a használatukkal járó kockázatokat is, s meg kellett őket tanítani az online tranzakciók biztonságos lebonyolítására, valamint a pénzügyi csalási és visszaélési kísérletek felismerésének a módjaira. Az európai országok például a kommunikációs csatornák szinte teljes spektrumát (webportálok, közösségi médiák, webes és televíziós tájékoztató kampányok, online pénzügyi műveltségi napok/hetek stb. formájában) vették igénybe ahhoz, hogy tájékoztatást adjanak számos olyan időszerü pénzügyi kérdésről, amellyel a fogyasztók mindennapi életük során szembesülhetnek, valamint felhívják a figyelmet a háztartások pénzügyeit közvetlenül érintő jogszabályi változásokra, továbbá a kiberbűnözés elleni védekezésre. Ezek a kezdeményezések különösen azokat az embereket célozták meg, akik nem rendszeres szereplői pénzügyi piacoknak, vagy akik fiatal koruk miatt még tapasztalatlanok, vagy olyan idősebb korú emberek, akik a járvány hatására nemrég tértek át a digitális eszközök használatára. A tájékoztatás nyújtása mellett ezek a csatornák a gyakran a fogyasztóvédelmet is szolgálták az elérhető pénzügyi termékek érthető összehasonlításával.

A járvány időszakában a pénzügyi oktatás és a fogyasztóvédelem terén nagy figyelmet kapott a kriptovalutákkal való kereskedés is. Amikor ugyanis a bitcoin árfolyama nem sokkal a koronavírus járvány kitörése után 2021 áprilisában történelmi csúcsra, több mint 60 ezer dollárra emelkedett, sokan kezdtek komoly érdeklődést tanúsítani e kriptovalutába történő befektetés iránt, talán arra is gondolva, hogy ha most nem szállnak be, akkor nagy lehetőséget szalaszthatnak el. 2021 novemberéig több mint 79 millió ember hozott létre egyedi bitcoin pénztárcákat a Blockchain.com oldalon, ami lehetővé teszi a bitcoin vásárlását. Ez körülbelül 31 százalékkal több, mint egy évvel korábban. ${ }^{20} \mathrm{Az}$ érdeklődést fokozta, hogy egyre több elemző jósolta: a kriptovaluták a digitális pénzügyi környezet állandó elemévé válnak, közben pedig számos online bróker meg tőzsdei platform próbált meg hírveréssel és különféle promócióval ügyfeleket megnyerni a

20 L. Josh Howarth (2022): How Many People Own Bitcoin? 95 Blockchain Statistics, https:// explodingtopics.com/blog/blockchain-stats. 
kriptovalutákba történő befektetéshez. Ám bármennyire szellemes is a bitcoin mögött meghúzódó innováció, a blokklánc, bármekkora figyelmet is vontak magukra a kriptovaluták, és bármennyit is költöttek a promóterek és a befektetők a kriptovaluta-kereskedés népszerüsítésére, a kriptovaluták és az instabilitás elválaszthatatlanok maradtak. ${ }^{21} \mathrm{~A}$ jövőt fürkésző jóslatok megoszlanak: vannak, akik a bitcoinpiac teljes összeomlását jósolják, de vannak, akik 100 ezer dollár feletti árfolyamot vizionálnak. Ilyen ellentmondásos kilátások közepette az átlagos kisbefektetők számára felelősen nem tanácsolható más, mint a kellő óvatosság, vagyis legfeljebb az egyénileg még elviselhető mértékű vesztesség erejéig történő befektetés.

Mint az a történeti áttekintésből kitünhetett, az, hogy a pénzügyi ismeretek oktatásával kormányzati szinten foglalkozzanak, alig több mint három évtizedes múltra tekinthet vissza. A pénzügyi ismeretek oktatásának előmozdítására irányuló kormányzati és kormányközi nemzetközi erőfeszítések pedig a 2008-as globális pénzügyi válság után sokszorozódtak meg. Napjainkban az egyes országokon kívül már szinte mindegyik gazdasági kérdésekkel foglalkozó, nemzetközi szervezet is feladatának tekinti valamilyen formában a pénzügyi befogadás előmozdításának, valamint a pénzügyi ismeretek oktatásának a kérdését. Történelmi léptékü távlatban nézve a kormányzati szintü eröfeszitések tehát még meglehetösen kezdeti szakaszban vannak. Ezzel, illetve az emiatt még szerény volumenü gyakorlati tapasztalattal függ össze az, hogy a pénzügyi oktatás hasznával, hasznosságával kapcsolatos nézetek még sokszor ellentmondanak egymásnak, illetöleg még nem kristályosodott ki konszenzus az egymással ütköző álláspontok között.

21 Mivel a bitcoin mögött nem áll klasszikus értelemben vett gazdasági háttér, a pénz számos fontos funkciójával nem rendelkezik. A bitcoin értéke mindig azon múlik, hogy a kriptopénz hívői milyen értéket tulajdonítanak annak, vagyis az egész teljesen szubjektív ítéleteken alapul. Mindemellett egy tanulmány szerint 10 ooo bitcoinszámlán 5 millió található a már forgalomban lévo 19 millió érméből, vagyis e kriptovalutának rendkívül koncentrált a piaca, s ezért az árfolyammozgás irányát a tulajdonosok töredékének a hangulata szabja meg. Ebből adódóan a bitcoin árfolyamváltozásának általános jellemzője, hogy szélsőséges tőzsdekilengéseket mutat: egy bitcoin értéke hetek, hónapok, sőt akár napok alatt rendkívüli mértékben megnőhet vagy lecsökkenhet. A bitcoin árfolyamának hullámvasútja a 2021. évi tavaszi csúcsot követő nyári 30 ezer dolláros mélypontról ismét meredeken száguldott felfelé, s november elején 67 ezer dollár feletti rekordárat ért el. Ezt a 2022 januári zuhanás követte, amelyet nagyrészt a kazahsztáni politikai zavargások, valamint az kísérő internetleállás váltott ki. 


\section{A HATÉKONY PÉNZÜGYI OKTATÁS KÖLTSÉGEI}

Az oktatási rendszer hatékonyságát általában az igénybe vett anyagi és emberi erőforrásoknak és azok hasznosulásának az egybevetésével mérik. Nincs ez másképpen a pénzügyi oktatás terén sem. Bár az ismeretanyag átadása többnyire a meglévő tanterv és tananyag kiegészítésével, a rendelkezésre álló tanerő és oktatási infrastruktúra felhasználásával történik, elkerülhetetlenül szükség van többleterőforrásokra (pl. tanárok továbbképzésére, kiegészítő tananyagra és segédeszközökre stb.). A ráfordítások mérése és azok nemzetközi összehasonlítása nem okoz különösebb gondot, mivel a számbavétel módját és a használt kategóriák tartalmát illetően egységes megközelítést alkalmaznak. Ugyanakkor az oktatáshatékonyság mérését még a kiforrott módszerek hiánya jellemzi. ${ }^{22} \mathrm{Az}$ pedig az oktatás-gazdaságtanban járatlan szakemberek számára is könnyen belátható, milyen nehéz meghatározni azt, hogy mi is tekinthető a pénzügyi oktatás „hozamának", és az miként mérhető, illetve miként fejezhető ki pénzben.

A nemzetközi gyakorlat szerint az oktatás eredményességének a vizsgálata alapvetően a tanulói teljesítmény mérésén alapszik. E tekintetben a tanulmányi időszak során bekövetkezett változást próbálják megragadni, azaz felmérik a kezdeti ismeretszintet, amelyet az oktatás végén elért ismeretszinttel vetnek egybe. Az eddigi pénzügyi oktatási programok utóvizsgálatai azt mutatták, hogy a féléves középiskolai képzés, illetőleg a felnőttképzésben alkalmazott. néhány hónapos tanácsadási kurzusok nem eredményeztek számottevő és maradandó növekményt a tudásszintben, mivel egyfelől a szükséges mennyiségü ismeret elsajátításához, valamint annak gyakorlati feldolgozásához hosszabb időre van szükség. (Jobb eredményeket sikerült felmutatni a diákok nemzetközi vetélkedőin, de persze itt a hosszabb és módszeres felkészülés volt a siker záloga.) Másfelől - mint arról már ugyancsak szó esett - az átadott ismeretek egy része az idő múlásával menthetetlenül elavul, s ezért elértéktelenedik.

Azt sem szabad szem elől téveszteni, hogy a tanulók által elért teljesítményre az egyéni adottságokon, valamint a család és a baráti kör befolyásán kívül - a legújabb kutatások szerint erőteljesen hatnak az osztályteremben történtek, valamint az iskolavezetés kultúrája is. E tekintetben pedig az egyes iskolák között számottevő különbségek mutatkozhatnak egyfelől amiatt, hogy milyen adottságú és milyen ismerettel rendelkező tanárok és vendégelőadók adják le a tananyagot, másfelől amiatt, hogy az iskolavezetés mennyire elkötelezett a pénzügyi ismeretek oktatása iránt.

22 L. pl. BALÁzs Éva (1996): Az oktatás hatékonysága: problémák, fogódzók, lehetséges megközelítések, intézményi szinten. Iskolakultúra, 6(6-7), 3-10. http://www.iskolakultura.hu/index.php/ iskolakultura/article/view/31339/31056. 
A hatékony pénzügyi oktatás igen költséges is lehet.

1) Ennek egyik lehetséges oka az, hogy az oktatásban részesülő diákok (vagy felnőttek) „induló” ismeretszintjében jelentős különbségek mutatkoznak. A beiskolázottak alacsony „induló” ismeretszintje esetén pedig a hatékony pénzügyi oktatásnak időtartamban hosszabbnak, tematikájában pedig bővebbnek kell lennie, hiszen néha akár az alapvető pénzügyi matematikai feladatok elvégzésétől az egyes információforrások megbízhatóságának értékeléséig terjedő, széles spektrumban kell ismereteket átadni.

2) Másfelől a hatékony pénzügyi oktatás költségigényét növeli a pénzügyi döntések összetettsége, valamint a fogyasztók pénzügyi helyzetének és személyes preferenciáinak a sokszínűsége is. Az olyan egyszerü hüvelykujjszabály, mint amilyet például az adósságfék-rendelet is elöír - amely szerint ötszázezer forint alatti havi jövedelem esetén a vállalható havi törlesztés legfeljebb a nettó jövedelem 50 százaléka lehet -, a változó kamatozású hiteleknél gyakori és/ vagy jelentősebb kamatlábváltozás esetében csak nagy fenntartással alkalmazható, amint azt a nemrégiben megjelent lakáshitelkamatstop-rendelet is mutatta. Ráadásul a különféle preferenciális hitelkondíciók, adókedvezmények és támogatások miatt könnyen előfordul, hogy ami az egyik fogyasztó számára optimális kombináció, az egy másik számára nem elérhető, vagy éppenséggel nem bizonyul a legmegfelelőbbnek. Ezen túlmenően, ha valakinek több hitel miatt áll fenn tartozása és nehéz pénzügyi helyzetbe sodródik, akkor csak részletes elemzéssel lehet meghatározni a tartozásainak a legcélszerűbb átstrukturálását, esetleges átütemezését. Ilyen bonyolult és szerteágazó ismeretet igénylő kurzust viszont aligha lehet hatékonyan megszervezni, ráadásul az szükségtelen is azok számára, akik nincsenek szorult helyzetben. Ezért ilyen esetekben inkább a „testre szabott”, ingyenes tanácsadás bizonyul az oktatásnál hatékonyabb megoldásnak.

3) A termékkínálat és az iparági szokások változásának gyorsasága jelenti a pénzügyi oktatás hatékonyságának a harmadik nehézségét. A fogyasztói igényeket és preferenciákat akár az új pénzügyi eszközök megjelenése, akár a divat változása, akár a külső kényszerek - mint a koronavírus-járvány esetében is történt - rendszeresen megváltoztathatják. Viszont az olyan nagy horderejü, hosszú távra szóló személyes pénzügyi döntések meghozatala, mint például egy lakáshitel felvétele, valamilyen nyugdíj-kiegészítő konstrukció kiválasztása vagy életkezdési számla nyitása a gyermek javára olyan egyszeri aktus, amelyet csak a kötelezettségvállalás időpontjára lehet optimalizálni. A megkötött ügyletek tartós kötelezettséget rónak a fogyasztóra még akkor is, ha egyes feltételeken a későbbiekben lehet változtatni. A munkás hétköznapjaikat élő fogyasztók többsége azonban nem tudja követni a rendszeresen bekövetkező változásokat, amelyek egyébként az iskolai pénzügyi oktatás ke- 
retében szerzett ismereteiket is avulttá teszik. Néhány évtizeddel ezelőtt például még „hüvelykujjszabálynak” számított: az éves jövedelem egytizedét kell a nyugdíjas korra félretenni ahhoz, hogy ne kelljen majd a megszokott életszínvonalból sokat feladni. Ám a várható élettartam örvendetes meghosszabbodása, továbbá ezzel is összefüggésben az időskori gyógykezelési és ápolási költségek alakulására vonatkozó előrejelzések viszont azt jelzik, hogy a jövőben 10 százalékos megtakarítás már nem lesz elegendő ehhez, vagyis kinekkinek a preferenciáitól függően időről időre újra kell gondolnia, hogy mennyit tesz félre öreg napjaira. Következésképpen a pénzügyi oktatás hatékonysága csak az ismeretanyag rendszeres megújításával lenne biztosítható, ami viszont nehezen szervezhető meg és tetemes költségekkel is járhat, kiváltképpen azért, mert felnőttkorban az iskolai képzés már nem jön szóba.

4) Negyedszer az új ismeretek elsajátítása iránti érdeklődés hiánya vagy a továbbképzésben történő részvételtől való ódzkodás a pénzügyi oktatásban olyan további akadályt jelent, aminek a leküzdése szintén nehéz és költséges. $\mathrm{Az}$ önkéntes részvételen alapuló pénzügyi oktatás a digitális technikáknak köszönhetően ma már ugyan széles körben, szinte bárhol és akár ingyenesen is elérhető, ám ezt a lehetőséget az emberek többsége mégis csak ritkán vagy egyáltalán nem veszi igénybe. Egy vizsgálat szerint például, amikor a hitelkártya-kibocsátók több ezer hitelkártya-tulajdonost figyelmeztettek arra, hogy csalás és visszaélés kockázatának vannak kitéve, és ezért számukra az esetleges károk megelőzéséhez egy ingyenes online tanfolyamon való részvételt ajánlottak fel, a megkeresett ügyfeleknek csupán o,4 százaléka jelentkezett be a megadott webhelyen, a jelentkezőknek pedig mindössze az egytizede végezte el a tanfolyamot. Az pedig egyenesen ironikusan hat, hogy azoknak a többsége, akik elvégezték a kurzust, eleve az átlagosnál nagyobb pénzügyi tudással, jobb költségvetési és tervezési készségekkel rendelkezett, mint azok, akik számára jóval hasznosabb lett volna a részvétel, ám nem éltek a felajánlott lehetőséggel. Ilyen és ehhez hasonló esetben az oktatás hatékonyságát paradoxnak tűnő módon a részvétel kötelezővé tétele biztosíthatta volna, ami viszont gyakorlatilag kivitelezhetetlen.

5) Ötödször: a pénzügyi szolgáltatások szektora jelentős forrásokkal rendelkezik az ügyfeleinek intenzív marketing- és reklámtevékenységgel történő befolyásolására. Amikor a felügyeleti hatóságok és a fogyasztóvédelmi szervezetek felvilágosító kampányokat indítanak bizonyos megtévesztő üzleti feltételekkel és gyakorlattal szemben, akkor szinte valamennyi érintett szolgáltató gyorsan megváltoztatja a marketingjét, és fennen hangoztatja a maga megbízhatóságát és üzleti tisztességét. A marketing- és reklámeszközök nagy befolyására tekintettel az oktatás akkor bizonyulna igazán hatékonynak, ha az ismeret átadása lehetőleg a döntéshozatal helyén és időpontjában történne. Ezt viszont nehéz 
megoldani, továbbá nyilván tetemes költségekkel járna, aminek a finanszírozására aligha lehetne közpénzt találni.

6) Hatodszor: a pénzügyi oktatás hatékonysága szempontjából az is komoly kihívás, hogy még felsőfokú végzettséggel rendelkező és pénzügyileg tájékozott személyek is meglepően gyakran hoznak hibás pénzügyi döntéseket. A logikus döntéshozatalt ugyanis számos elöítélet, hirtelen ötlet vagy éppen pillanatnyi hangulat is befolyásolhatja, amit a viselkedési pénzügytan ${ }^{23}$ megfigyelései jól dokumentálnak a személyes pénzügyek területén is. Az emberi döntéshozatal fontos jellemzői a kognitív torzítások, vagyis az olyan rendszeresen előforduló gondolkodási hibák, amelyek a logikával vagy akár az elfogadott viselkedési szabályokkal ellentétes döntések meghozatalához vezetnek. A pénzügyek terén ennek egyik gyakori oka a termékválaszték bősége, továbbá a döntési lehetőségek teljes felméréséhez szükséges információk nagy mennyisége, mert ezek egyes fogyasztóknál túlzottan leegyszerüsített döntési stratégia alkalmazásához, mások esetében viszont krónikus döntésképtelenséghez vezetnek. Ráadásul egyes döntések jelentős tétje sokszor komoly stresszt vált ki az emberekben, ami mentális erőforrásokat köt le, ez pedig gyakran arra vezet, hogy a döntéshozó figyelmen kívül hagy akár több lényeges szempontot is. A fontos pénzügyi döntések meghozatala ugyanis számos, a munkahely elvesztésétől az egészségügyi problémákig terjedő kockázat vagy veszélyhelyzet valószínűségének, várható bekövetkezési időpontjának és költségeinek a gondos mérlegelését követeli meg. Ám ezeket a kockázati tényezőket az egyes fogyasztók vagy teljesen elhanyagolják, vagy túlzott optimizmussal becsülik meg. Ráadásul a meghozandó pénzügyi döntés esetleges kedvezőtlen következményei gyakran csak évek múlva válnak felismerhetővé vagy érzékelhetővé, az emberek viszont hajlamosak kevés figyelmet szentelni a távolabbi jövőben jelentkező vagy bizonytalannak tűnő következményeknek. Ezért sok bonyolult vagy nagy összegű pénzügyi termék értékesítése gyakran a forgalmazó által kimunkált egyetlen jövőbeni kimenetel feltételezése alapján történik, a fogyasztók egy része pedig könnyedén hagyatkozik erre az egy kimenetelre.

7) Végül, de nem utolsó sorban egyes fogyasztókat a saját képességeikbe vetett túlzott magabiztosság jellemez, másokat meg éppen ellenkezőleg, az indokolatlan kishitűség. Egy felmérés szerint például a válaszadók több mint 16 százaléka a legmagasabb szintűnek értékelte a saját pénzügyi tudását, noha a teszt szerinti teljesítményük az alsó kvartilisben volt, viszont több mint 8 százalékuk, akiknek a teszteredménye a felső kvartilisbe tartozott, a saját

23 L. https://evk.hu/blog/2021/o1/o2/a-viselkedesi-kozgazdasagtan-eredete-fogalma-es-alkalmazasanapjainkban/, és különösen KovÁcs-TERTÁK (2019). 
tudását a legalacsonyabb szintünek értékelte. Megdöbbentőnek tünhet, de a felmérések szerint a túlzott magabiztosság föleg az alacsony pénzügyi ismerettel rendelkezőket jellemzi, míg a magasabb szintü tudás gyakran a saját képességek alábecsülésével társul. Természetesen bizonyos lélektani technikákkal lehet mérsékelni a kognitív torzítások hatásait, ám ezeket már csak a költségvonzatuk miatt sem lehet egységesen alkalmazni a teljes népességnél. Ráadásul óvatosan kell eljárni a túlzott magabiztosság lefaragása során, mert a tapasztalatok szerint, ha például valakit arra kérnek meg, hogy nevezzen meg bizonytalan, de számára kedvezőtlen jövőbeli eseményt - például az állásának az elvesztését vagy váratlan egészségügyi kiadásokat - akkor az inkább az illető elbizonytalanodásához vezethet, semmint a kockázat megbízható becsléséhez.

Az eddigiekböl logikusan az következne, hogy a hatékony pénzügyi oktatásnak lehetőleg kiterjedtnek, rendszeresnek, sőt egyenesen kötelezőnek kell lennie; az oktatást célszerü volna a döntéshozatal helyére és időpontjára fókuszálni, tartalmát pedig lehetőleg személyre kellene szabni. Csakhogy az összes kívánalom egyidejű teljesítésének az idő- és pénzigénye valószínűleg a többszörösét tenné ki a szokásos közoktatási kampányoknak, emellett a megvalósításhoz egy magasan kvalifikált, jól megfizetett, független pénzügyi oktatói és tanácsadói gárdát kellene létrehozni és fenntartani. Az pedig meglehetősen kétségesnek tűnik, hogy mindennek a teljes ráfordításigénye kevesebb volna az oktatás társadalmi szintü hasznánál. Ráadásul a kognitív torzítások hatásait mérséklő eljárások többsége valószínűleg még a magánéletbe történő indokolatlan beavatkozásnak is minősülhetne. Józanul be kell tehát érni azzal, hogy a pénzügyi oktatás optimális esetben is csak olyan és annyi ismeretet képes hatékonyan átadni, ami lehetövé teszi a részvevők számára, hogy konkrét esetben képesek legyenek felismerni: mi mindennek és hol kell utánajárniuk ahhoz, hogy megalapozott döntést hozhassanak. Továbbá tudomásul kell venni azt is, hogy az oktatás során átadott ismeret nem minden részvevőben ragad meg, egy része pedig annak az ismeretnek, ami megragad, idővel elavul. Ugyanakkor látni kell, hogy az említett korlátok mellett is a pénzügyi ismeretek iskolai oktatásába befektetett források hasznosulása nem rosszabb, mint más tantárgy - például a biológia vagy az irodalom - tanítására fordított forrásoké.

A pénzügyi oktatás költségei kapcsán indokolt említeni ezek finanszírozását is. A pénzügyi oktatás oroszlánrészét a közoktatási rendszer valósítja meg, és annak keretében történik a finanszírozása is. A felnőttek pénzügyi képzése is közhasznú tevékenységnek számít, azonban azt gyakorlati okokból is az iskolarendszeren kívül végzik; azt többnyire közpénzből az önkormányzatok és a szakszervezetek, jóléti juttatásként pedig a munkáltatók szervezik és pénzelik. Ugyanakkor világszerte tapasztalható, hogy egyre több pénzügyi szolgáltató, s még inkább azoknak a szakmai szövetségei készek komoly anyagi és szellemi erőforrást szánni a pénz- 
ügyi oktatás céljaira, jóllehet a pénzügyi oktatás egyik fö célja a nemzetközi szakirodalom szerint is az, hogy a fogyasztókat felvértezze a pénzügyi szolgáltatók ajánlatainak kritikus értékelésére. A pénzügyi szolgáltató szektornak a pénzügyi oktatást segítő konkrét példái a már említett Európai Pénzügyi Oktatási Platform vagy az amerikai Jump\$tart Coalition; de számos nemzeti szakmai szövetség köztük hazánkban a Magyar Bankszövetség és a Magyar Biztosítók Szövetsége -, valamint több pénzügyi vállalkozás is szervez vagy támogat pénzügyi oktatást szolgáló programot. ${ }^{24}$

A magáncégek és magánszervezetek támogatása természetesen nem teljesen önzetlen: sokszor azért karolnak fel iskolai pénzügyi oktatási programokat, mert ez jó marketinglehetőséget is teremt a számukra például a fiatal ügyfelek megnyeréséhez. Ám sok cég akkor is szponzorál pénzügyi oktatást, ha nincs közvetlen ráhatása azok tartalmára, nem származik belőle közvetlen haszna, vagy az nem növeli közvetlenül a hírnevét.

Vajon a nyereségorientált vállalkozásokat mi motiválja ilyen áldozatvállalásra? A cégek egy része attól tart, hogy ha nem lehet a pénzügyi oktatást a fogyasztók pénzügyi problémáinak egyik lehetséges és hatásos kezelési módjaként felmutatni, akkor a szabályozás más, invazív és költséges formáival kell majd szembenézniük. A vállalkozások egy másik köre pedig úgy véli, hogy egyes új termékeket vagy új digitális eszközöket akkor lehet igazán gyorsan és sikeresen bevezetni és elterjeszteni a piacon, ha reklámozás helyett semlegesnek és pártatlannak tűnő módon, oktatás keretében mutatják be ezeket, és tanítják meg az ügyfeleiket a biztonságos használatukra. Különösen a kiberbiztonság terén kifizetődő az ügyfeleknek a felügyeleti hatóságokkal és a rendőri szervekkel közösen történő felvilágosítása vagy oktatása, mert az ilyen közös fellépéseknek általában nagyobb hitele és hatása van az ügyfelek körében, s ez pedig elősegíti a kiberbünözés miatt fenyegető károk sikeresebb megelőzését vagy mérséklését; e károk egy részét pedig egyébként a pénzügyi szolgáltatóknak kellene viselniük.

24 Részletesebb ismertetés az EU belüli közösségi és nemzeti kezdeményezésekről az Európai Gazdasági és Szociális Bizottság kiadványában (EESC, 2016) található. 


\section{NÉHÁNY GONDOLAT A PÉNZÜGYI OKTATÁS ÉS A PÉNZÜGYI SZABÁLYOZÁS VISZONYÁRÓL}

A pénzügyi oktatást sokan tartják a fogyasztók autonómiáját megerösítő, egyszersmind a túlzottan beavatkozó szabályozást feleslegessé tévő, de legalábbis azt mérséklő megoldásnak. Nézeteik fó érve az, hogy a túlzottan részletekbe menő szabályozás korlátozza a fogyasztók szabad választásának a lehetőségét, ezáltal pedig végső soron kiskorúsítja a fogyasztókat. Ezzel szemben az oktatás képessé teszi a fogyasztókat arra, hogy a pénzügyeikben a saját kezükben tartsák a döntést.

Csakhogy a valóságban maga a hatékony pénzügyi oktatás járhat sokszor az egyéni autonómiába történő jelentős beavatkozással. Társadalmi szempontból ugyanis csak a mindenkire kiterjedő és kötelező pénzügyi oktatás tekinthető hatékonynak, ezért azokat is az oktatásban való részvételre kényszerítené, akik valamilyen okból nem kívánnak részt venni az oktatásban.

Másodszor, a kognitív torzítások kiküszöbölése csak az emberek gondolkodási folyamatainak, érzéseinek, motivációinak és végső soron értékeinek a befolyásolásával, megváltoztatásával lehetséges. A túlzottan magabiztos embereket például rá kell venni arra, hogy körültekintőbbek és óvatosabbak legyenek döntéseik meghozatala során. A türelmetlen embereket pedig arra kell rábírni, hogy az időtényezőnek kisebb jelentőséget tulajdonítsanak, vagyis döntéseik meghozatalában a gyorsaság csupán az egyik tényező legyen.

A fizetési nehézségeknek a kezelése a pénzügyi tudatosságnak és oktatásnak növekvő fontosságú területét jelenti.

1) Egyfelől azért, mert a háztartások adósságállománya az EU-országokban például a háztartások éves jövedelmének a 35 és 206 százaléka közé esik ${ }^{25}$, a magas eladósodottság pedig óhatatlanul magas sérülékenységgel jár.

2) Másfelöl azért, mert sok ember önhibáján kívül is kerülhet olyan anyagi helyzetbe, amikor a korábban vállalt kötelezettségeinek nem képes időben és öszszegében maradéktalanul eleget tenni, viszont a fizetési késedelem többnyire súlyos szankciókat von maga után. Ilyen helyzetekben az érintettek rendszerint külső tanácsra szorulnak. Nem csupán azért, mert járatlan embernek nehéz felmérnie és kidolgoznia a kialakult helyzet optimális kezelésének jogi és pénzügyi megoldását, hanem azért is, mert a felmerült gondok miatti szorongás és a következményektől való félelem többnyire bénító stresszállapotba sodorja az érintettet, ami tovább súlyosbíthatja az amúgy is nehéz helyzetét.

25 Eurostat (2021): Gross debt-to-income ratio of households (in 2020), https://ec.europa.eu/ eurostat/databrowser/view/tecoo104/default/table?lang=en. 
Ilyen helyzetben tehát az érintett személy pénzügyi és mentálhigiénés szakemberek közös tanácsára és segítségére szorul ahhoz, hogy a hitelezőknek teljes körü és pontos információkat tudjon adni a pénzügyi helyzetéröl, egyszersmind hihető és felelősen vállalható rendezési javaslatot tudjon előterjeszteni. A rendezési megállapodás megkötése és föleg annak teljesítése nem egy egyszeri aktus, többnyire szükségessé teszi azt is, hogy az adós megváltoztassa a pénzzel való gazdálkodása addigi gyakorlatát. A viselkedéstudomány által kidolgozott, hagyományos „nudge” (magyarul: enyhe lökés, ösztökélés) ${ }^{26}$ úgy idéz elő változást a viselkedésben, hogy segít módosítani bizonyos kérdésekhez való hozzáállást és szokásokat. Erre a fajta ösztökélésre pedig azért van szükség, mert gyakran összetett folyamatok, máskor mérlegelési hiányosságok tartják vissza az embereket attól, hogy olyan döntéseket hozzanak, amelyek tartósan jó hatással lennének az életükre. A bajba került emberek viselkedésének a megváltoztatása nyilván kedvező hatással jár számukra, ám elengedhetetlenné teszi az olyan célzott pénzügyi oktatásban való részvételt, amely óhatatlanul szűkíti a döntési önállóságukat.

3) Harmadszor, az oktatási programok kidolgozása során el kell dönteni, hogy milyen ismereteket kell tanítani olyan háttér mellett, amelyben még nincs általános egyetértés arról, hogy mi is minősül helyes pénzügyi viselkedésnek. Például a nyugdíj-kiegészítő előtakarékosság egyéni stratégiájának a kialakításához olyan előrejelzéseket kell a különböző befektetési lehetőségek várható hozamára nézve mérlegelni, amelyek nagyságát illetően még a szakértők prognózisai között is jelentős eltérés mutatkozik. Hasonlóképpen a megfelelő befektetés kiválasztása is kompromisszumokat igényel a kockázat és a hozam között, ami felveti annak a kérdését is, hogy vajon mekkora pénzügyi kockázatot szabad és kell vállalnia egy egyénnek vagy egy háztartásnak. A pénzügyi oktatás nem tekinthető hatékonynak akkor, ha megkerüli ezeket az igencsak gyakorlati kérdéseket. Az a fogyasztó, aki a nyugdíjtervezési segédleteknek olyan „ajánlásait” követi, amely szerint minden egyes befektetési eszközre maga válasszon ki egy megtérülési rátát attól függően, hogy mennyire bízik az adott eszköz növekedési kilátásaiban, bizony semmilyen érdemi segítséget sem kapott a döntéséhez. Hasonlóan nem sok segítséget jelent az olyan tanács sem, ami ismerteti az adósságfék szabályait, de nem ad támpontot ahhoz, hogy az adott jogszabályi korlátokon belül konkrétan mit is kell mérlegelni egy felvenni tervezett lakásvásárlási hitel kapcsán.

26 L. https://viselkedestudomany.hu/nudge/ weboldalt és az OGY (2020): A Képviselôi Információs Szolgálat háttéranyagai, Infojegyzet 2020/4, Viselkedési közgazdaságtan, https://www. parlament.hu/documents/10181/4464848/Infojegyzet_2020_4_viselkedesi_kozgazdasagtan.pdf/ cfcb814c-98ee-5fbb-72od-6d7a552e570o? $t=1581950730688$. 
A legtöbb oktató tisztában van mindezzel, és ezért igyekszik is a legjobb tudása szerint a diákjait olyan gyakorlati ügyekben eligazítani, hogy megtakarításaikat milyen befektetési termékbe érdemes elhelyezni, vagy lakásvásárlás esetén a rendszeres jövedelmüknek mekkora hányadát szabad kölcsönnel megterhelni. Bár ezek a tanácsok szakmai és etikai szempontból bizonyára korrektek, óhatatlanul a tanár személyes meggyőződését és preferenciáit tükrözik. Azok a diákok tehát, akik fenntartások nélkül elfogadják és követik az iskolában kapott tanácsokat, akaratlanul lemondanak a döntési autonómiájukról, viszont követő magatartásuk következményeit ugyanúgy kell viselniük, mintha valóban önálló döntést hoztak volna.

\section{A PÉNZÜGYI OKTATÁS LEHETSÉGES ALTERNATÍVÁI}

A pénzügyi oktatás apostolai úgy vélik, hogy a személyes autonómiát és az egyéni felelősséget az teremti meg, ha az egyént a szabályok és a körülmények arra szorítják, hogy valamennyi pénzügyi döntését maga hozza meg a legjobb tudása és ismeretei alapján. Csakhogy sokan az egyes összetettebb pénzügyi termék sajátosságainak a megismerését vagy a háztartási kiadásaik nyilvántartását és megtervezését nyügnek érzik, mert szerintük az komoly szellemi erőfeszítést, no meg túl sok időt venne igénybe. Emellett arról sem szabad megfeledkezni, hogy az emberek meglehetősen eltérő beállítottsággal rendelkeznek bárminemü pénzügyi veszteség elviselése iránt. ${ }^{27}$ Minden negyedik befektető például kifejezetten elviselhetetlennek érez bárminemű anyagi veszteséget, továbbá retteg a megbánás érzésétől, ezért amennyiben attól tartanak, hogy döntésük kedvezőtlen kimenettel jár, inkább nem is hoznak semmilyen döntést. Ha pedig mégis döntésre kényszerülnek, akkor úgy igyekeznek ennek lelki terhe alól kibújni, hogy pénzügyi tanácsadóhoz fordulnak, vagy a családjuk, a barátaik, esetleg munkatársaik tanácsát kérik. Ezért paradoxnak tűnő módon sokak számára az jelent nagyobb szabadságot, ha az adott ügyletre vagy a pénzügyi szolgáltatóra vonatkozó kötelező szabályok, előírások „megkímélik” őket pénzügyeikben a mérlegeléstől és a saját döntés meghozatalától.

A pénzügyi oktatás hívei persze hangsúlyozzák, hogy céljuk egyáltalán nem egy olyan világ megteremtése, amelyben a pénzügyi oktatás teljesen feleslegessé teszi a szabályozást, hanem csupán az, hogy segítséget nyújtsanak a fogyasztóknak a felelős választásban és döntéshozatalban. Ám ha tényleg csak az a cél, hogy egy adott személy többet fordítson és okosabban fektessen be a nyugdíjának a

27 L. erről bővebben a DANiel KAHNEMAn és Amos Tversky által 1979-ben kidolgozott kilátáselméletet (eredeti nyelven: „Prospect theory”), https://doi.org/10.2307/1914185. 
kiegészítésére, akkor ennek eléréséhez vajon miért éppen a pénzügyi oktatás a legolcsóbb megoldás? Hiszen a biztonsági hálók és garanciák megerősítésével, valamint megfelelő előírásokkal feltehetően hasonló végeredményt lehet elérni, esetenként talán olcsóbban és nagyobb bizonyossággal.

Vagy ha például az az elérni kívánt cél, hogy a fogyasztók csak olyan összegü és feltételű jelzáloghiteleket vegyenek fel, amelyeket a jelenlegi és a várható jövedelmi helyzetükben maguknak megengedhetnek, akkor vajon társadalmi szinten nem lenne-e olcsóbb alternatíva egy megfelelő szabályozás? Olyan például, amely a hitelnyújtókat kötelezi arra, hogy ügyfeleiknek csak olyan feltételü és akkora összegü hitelt nyújtsanak, amelyet azok a jövedelmi és vagyoni viszonyaik alapján biztonsággal képesek lesznek törleszteni.

A legtöbb elérni kívánt cél esetében lehet alternatív megoldásokat találni, ezért minden esetben indokolt megvizsgálni azt, hogy a pénzügyi oktatás esetén felmerülő költségek hogyan viszonyulnak az alternatív megoldások költségeihez, tehát például a pénzügyi szolgáltatóra vonatkozó előírások alkalmazásához, vagy a fogyasztók részére díjmentesen nyújtott, személyre szabott tanácsadás költségeihez. Ez utóbbi alternatívát egyébként már csak azért is indokolt mérlegelni, mert amint nem várható el az emberektől, hogy ha rászorulnak, a maguk orvosai, ügyvédjei vagy autószerelői legyenek, úgy azt sem lehet tőlük elvárni, hogy saját maguk pénzügyi tanácsadóivá képezzék ki magukat.

$\mathrm{Az}$ 1. táblázat bemutatja a pénzügyi kultúra és a fogyasztóvédelem egymást kölcsönösen kiegészítő és erősítő eszköztárát. Minden külföldi és hazai tapasztalat azt mutatja, hogy a szabályozás és az oktatás két olyan egymást kiegészítő teendő, amelyeket a konkrét témától és körülményektől függően kell összehangolni.

\section{1. táblázat}

\section{Pénzügyi kultúra és a fogyasztóvédelem - egymást kölcsönösen erősítő eszköztár}

\begin{tabular}{|c|c|}
\hline Pénzügyi kultúra & Fogyasztóvédelem \\
\hline Oktatás & Jogi és szabályozási eszközök \\
\hline $\begin{array}{c}\text { A döntéshez szükséges információ } \\
\text { megértetése }\end{array}$ & $\begin{array}{l}\text { Döntéshez szükséges } \\
\text { információ átadása }\end{array}$ \\
\hline $\begin{array}{l}\text { A felkészült fogyasztó nagyobb versenyre } \\
\text { készteti a pénzügyi közvetítőket }\end{array}$ & $\begin{array}{l}\text { Meggátolja a szolgáltatók erőfölénnyel való } \\
\text { visszaélését (versenysemlegesség) }\end{array}$ \\
\hline $\begin{array}{l}\text { Lehetőséget kínál a kibővült, } \\
\text { de kockázatosabb mozgástér előnyeinek } \\
\text { kihasználására }\end{array}$ & $\begin{array}{l}\text { Védelmet nyújt, } \\
\text { aminek ára lehet a csökkenő választási } \\
\text { szabadság és mozgástér }\end{array}$ \\
\hline
\end{tabular}

Forrás: MNB (2006): A pénzügyi kultúra helye, szerepe és jelentösége az oktatásban, a fiatalok nevelésében címü konferencia anyagai (2006.10.03.). 


\section{KÖVETKEZTETÉSEK}

A felgyülemlett nemzetközi és a hazai tapasztalatok egyaránt azt támasztják alá, hogy a szabályozás mellett a pénzügyi oktatás is elengedhetetlen a fogyasztók pénzügyi biztonságának a növeléséhez, pénzügyi helyzetének a javításához. Ugyanakkor sem szakmai, sem pénzügyi szempontból nem indokolt túlzott elvárásokat támasztani a pénzügyi oktatással szemben. Egyrészt azért, mert bármely más tantárgy oktatásához hasonlóan a pénzügyi oktatás is egyénenként eltérö ismeretszintet generál. A pénzügyi ismeretekre ugyan az élete során mindenkinek többször és inkább szüksége lehet, mint például a biológia tantárgy keretében tanultakra, ám azt is tudomásul kell venni, hogy az oktatás során szerzett tudás a pénzügyi ismeretek terén szintén egyénenként eltérő módon hasznosul majd. Éppen e különbségek miatt is kell a szabályozás eszközeivel a szolgáltatókra hatni: még véletlenül se tehessenek anyagi előnyre szert abból, hogy az ügyfeleiknek a pénzügyi felkészültsége igencsak eltérő szintü.

Másrészt a pénzügyi szolgáltatások kínálata szakadatlanul változik, szinte nap mint nap születnek új konstrukciók. A pénzügyek terén napjainkban zajló digitalizációs forradalom is jócskán kiszélesíti az igénybe vehető szolgáltatások körét, ám egyúttal megnöveli az azok rendeltetésszerü és biztonságos használatához szükséges ismeretek mennyiségét is. A termékek és a technológiák terén végbemenő, számos változás egyfelől szükségessé teszi a szabályok folyamatos korszerüsítését és karbantartását, másfelől óhatatlanul avíttá teszi a pénzügyi oktatás keretében elsajátított ismeretek egy részét is. Ebből pedig egyértelműen két dolog következik:

1. A pénzügyi oktatás keretében a lexikális ismeretek átadása helyett azt a készséget kell kialakítani, hogy az emberek adott esetben képesek legyenek felismerni azt, mi mindennek és hol lehet utánajárni ahhoz, hogy megalapozott döntést tudjanak hozni.

2. Lehetőséget kell teremteni ahhoz, hogy a szüntelenül avuló ismeretanyagot legalább az érdeklődők rendszeresen felfrissíthessék.

Tekintettel arra, hogy olyan horderejű ügyek, pénzügyi döntések csak ritkán fordulnak elö egy-egy ember életében, amelyek szerteágazó és különleges szakismeretet igényelnek, ezért az ilyenfajta specifikus ismereteket felesleges is az oktatásba „beszuszakolni”, ehelyett tanácsadás keretében célszerü azokat hozzáférhetővé tenni. Annál is inkább, mert a tanácsadást a szabályozás nem tudja „kiváltani”, hiszen a szabályozás a természeténél fogva normatív jellegü, ezért a személy- és esetspecifikus problémákat csak tanácsadás keretében lehet kezelni. Ma már számos független professzionális tanácsadó szolgáltatása érhető el a piacon, bár ezek igénybevétele kétségtelenül költséges. Ezért azoknak a kis jövedelmű embereknek, akik anyagi okokból nem tudnak hivatásos tanácsadót igénybe venni, vagy 
azok számára, akiknek a pénzügyi döntések meghozatala pszichésen kimerítő feladatnak tünik, végezetül mindazok számára, akik önhibájukon kívül kerülnek pénzügyi nehézségbe, valamilyen formában lehetővé kell tenni, hogy kedvezményes feltételekkel, vagy akár ingyenesen kaphassanak tanácsot.

A pénzügyi oktatás - a bemutatott hasznai miatt, és minden említett korlátja ellenére is - olyan közérdekű és közhasznú tevékenység, amely hozzájárulhat a társadalom és az egyének jólétének a növeléséhez. A pénzügyi ismeretek oktatásának a szervezése és finanszírozása ezért döntően közfeladat. Ám a képzésbe megfelelő jogi és etikai kereteken belül lehetséges, sőt indokolt is a pénzügyi szolgáltatókat és azok szakmai szervezeteit bevonni, mert ez a társadalomnak közvetlenül, e szervezeteknek pedig közvetetten hasznára válik.

\section{HIVATKOZÁSOK}

Arthur, Christopher (2011): Financial Literacy - Neoliberalism, the Consumer and the Citizen (thesis). Toronto: Ontario Institute for Studies in Education of the University of Toronto. https:// tspace.library.utoronto.ca/handle/1807/30071.

Balázsné Lendvai Marietta (2006): Pénzügyi kultúránk fejlesztése mint a tudásalapú gazdaság megteremtésének egy fontos építőköve. In BGF Tudományos évkönyv, http://publikaciotar. repozitorium.uni-bge.hu/67/1/szf_19_02.pdf.

Balázsné Lendvai Marietta (2013): A bankmarketing szerepe a pénzügyi kultúra fejlesztésében (PhD-értekezés). Nyugat-magyarországi Egyetem, Sopron. http://doktori.uni-sopron.hu/id/ eprint/406/.

Batsaikhan, Uurintuya - Demertzis, Maria (2018): Financial literacy and inclusive growth in the European Union. Bruegel, Policy Contribution No o8, May 2018, https://www.bruegel. org/2018/05/financial-literacy-and-inclusive-growth-in-the-european-union/.

CsORBA LÁszló (2020) Pénzügyi kultúra és pénzügyi műveltség, a pénzügyi magatartás meghatározó tényezői. Pénzügyi Szemle, 1, 67-82. https://doi.org/10.35551/PSZ_2020_1_6.

Demirgüç-Kunt, Asli - Klapper, Leora - Singer, Dorothe - Ansar, Saniya - Hess, Jake (2018): The Global Findex Database 2017 - Measuring Financial Inclusion and the Fintech Revolution. World Bank, Washington D.C., https://openknowledge.worldbank.org/handle/10986/29510.

The Economist (2008a): Getting it right on the money - A global crusade is under way to teach personal finance to the masses. London, Apr 5 th ed.

The Economist (2008b): Ignorance is bliss. London, https://www.economist.com/freeexchange/2008/04/15/ignorance-is-bliss.

EESC (2016): European Economic and Social Committee: Financial Education for all - Financial education strategies and best practices within the European Union, $2^{\text {nd }}$ Edition, Bruxelles, https://www.eesc.europa.eu/sites/default/files/resources/docs/qe-02-16-362-en-n.pdf.

Gai, Prasanna -Kemp, Malcolm- Serrano, Antonio Sánchez - Schnabel, Isabel (2019): Regulatory complexity and the quest for robust regulation, ESRB Reports of the Advisory Scientific Committee No 8, June, https://www.esrb.europa.eu/pub/pdf/asc/esrb.asc190604_8_re gulatorycomplexityquestrobustregulation e63a7136c7.en.pdf.

Klapper, Leora - Lusardi, Annamaria - van Oudheusden, Peter (2016): Financial Literacy Around the World: Insights from the S\&P's Ratings Services Global Financial Literacy Survey. 
New York: McGraw Hill Financial Inc., https://gflec.org/wp-content/uploads/2015/11/Finlit_ paper_16_F2_singles.pdf.

Kovács Levente - Terták Elemér (2019): Financial Literacy - Theory and Evidence. Bratislava: Verlag Dashöfer, https://www.bankszovetseg.hu/publikaciok.cshtml?lang=eng.

Kollár Nóra EtelKa (2014): Működik a kilátáselmélet? - Empirikus vizsgálat a magyar fiatalok körében, Befektetések és Vállalati Pénzügy Tanszék Budapesti Corvinus Egyetem, http://szd.lib. uni-corvinus.hu/7570/.

KovÁcs Levente - NAGy ERNő (2022): A hazai pénzügyi kultúra fejlesztésének aktuális feladatai. Gazdaság és Pénzügy, 9(1), 2-19, https://doi.org/10.33926/GP.2022.1.1.

Kovács Levente - PÁsztor Szabolcs (2022): A pénzügyi kultúra az európai oktatásban. Gazdaság és Pénzügy, 9(1), 50-67, https://doi.org/10.33926/GP.2022.1.3.

Néмetr Erzséвeт (2022): A pénzügyi kultúrához kapcsolódó képzések. Gazdaság és Pénzügy, 9(1), 58-101, https://doi.org/10.33926/GP.2022.1.4.

NGM (2017): Pénzügyi tudatosság fejlesztésének stratégiája - Cselekvési terv a nemzeti stratégiához 2017-2019, Budapest, Nemzetgazdasági Minisztérium, https://2015-2019. kormany.hu/download/5/39/2100o/P\%C $3 \%$ A9nz\% $\mathrm{C}_{3} \% \mathrm{BCgyi} \% 2$ otudatoss\% $\mathrm{C}_{3} \% \mathrm{~A} 1 \mathrm{~g} \% 2 \mathrm{O}$ fejleszt\% $\mathrm{C}_{3} \% \mathrm{~A}_{9} \% \mathrm{C}_{3} \%$ A9nek\%2ostrat\% $\mathrm{C}_{3} \%$ A9gi\% $\mathrm{C}_{3} \%$ A1ja.pdf.

Németh Erzsébet - Vargha Bálint Tamás - Domokos Kinga (2020): Pénzügyi kultúra. Kik, kiket és mire képeznek? Összehasonlító elemzés 2016-2020. Pénzügyi Szemle, 65(4), 554-582. https:// www.penzugyiszemle.hu/documents/nemeth-vargha-domokos-20-4-mpdf_20201221175111_64. pdf.

OECD (2016): Financial Education in Europe - Trends and Recent Developments, Paris. https:// www.oecd.org/education/financial-education-in-europe-9789264254855-en.htm/.

OECD-INFE (2020): 2020 International Survey of Adult Financial Literacy, Paris. https://www.oecd. org/financial/education/oecd-infe-2020-international-survey-of-adult-financial-literacy.pdf.

OECD-INFE (2021): Report - Supporting resilience through digital financial literacy, Paris https://www.oecd.org/finance/financial-education/supporting-financial-resilience-andtransformation-through-digital-financial-literacy.htm.

Willis, Lauren E. (2010): The Financial Education Fallacy. Papers and Proceedings, American Economic Review, 101(3), 429-434. https://www.researchgate.net/publication/227362955_The_Financial_Education_Fallacy.

World BANK (2019): Global Financial Development Report 2019-2020 - Bank Regulation and Supervision a Decade after the Global Financial Crisis. https://www.worldbank.org/en/ events/2019/11/28/global-financial-development-report-2019-2020-bank-regulation-andsupervision-a-decade-after-the-global-financial-crisis. 